Journal of Environmental Sciences (JES)

Institute of Environmental Studies and Research, Ain Shams University

Adly, Michel. et al.

\title{
INVESTIGATING THE IMPACT OF EMPLOYING NANOTECHNOLOGY IN HERITAGE BUILDING RESTORATION (EGYTIAN ENGINEERS SYNDICATE)
}

\author{
Michel.G. Adly ${ }^{(1)}$; Magda Ebeid ${ }^{(2)}$ and Saied Zaki $^{(3)}$ \\ 1) Post graduate student at Institute of Environmental Studies \& Reesearch, \\ Ain Shams University. 2) Prof of Arch,Dep of Eng sciences Institute of \\ Environmental, Ain Shams university. 3) Prof of Strength and Testing \\ Materials, Housing and Building National Research Center (HBRC).
}

\begin{abstract}
In terms of the importance of restoring heritage buildings in Egypt, this research was initiated with the objective of evaluating the effect of usinginvestigating the impact of employing nanatechnology during rehabilitation on the concrete mechanical and physical properties, where Engineering Syndicate Building, in Ramses Square, was taken as a case study. A reseach methodology was planned to encompass theoretical, experimental, analytical and inferential investigations. Throughout the theoretical investigation, literature in the field of restoring heritage buildings and nanothnology were assembled and scrutinized. During the experimental investigation, nanoparticles mixes were produced (i.e. Nano Calcuim carbonate $(\mathrm{CaCO} 3)$ and Nano kaolin $(\mathrm{NK}))$. In addition, hybrid nanoparticle mixes, with different proportions of nano-CaCo3 and NK, were obtained. For comparison purposes, a reference mix was prepared. Furthermore, the impact of implementing nanoparticles, with different proportions, on concrete mechanical so as physical properties was examined. In addition, employing such mixes in old concrete restoration was investigated. All through the analytical investigation, the results were analyzed and interpreted. During the inferential investigation, conclusions so as recommendations were inferred. The results indicated that adding nanoparticles reduced the concrete


workability and its compressive strength, in comparison to the reference mix. Moreover, the reslts designated that the suitable amount of the nano-CaCo3 and NK nanoparticles were $1 \%$ and $5 \%$, respectively. On the other hand, the hybrid nanoparticle proper amount was $0.5 \%$ for nano-CaCo3 and $4.5 \%$ for NK. This proportion increased the hardening; achieved a better compressive strength so as adhesion to heritage building concrete and enhanced water permeability, in comparison to the reference mix. Innovative about this study is prioritizing the suitable nanoparticles proportions to ensure the efficient performance of concrete in heritage building restoration.

Key words: Heritage Building - Restoration - Nanoparticles - Hybrid

(*)correspondinganthor : mklgirgis88@gmail.com

\section{INTRODUCTION}

Heritage buildings are of significant historical and social value. Accordingly, Egypt prioritized the restoration of heritage buildings, where unconventional rehabilitation due to the significant environmental considerations. In the same context, Egypt is praised to have promising engineering experience in such a field.

The problem that faced the restoration process is that repairing heritage buildings with traditional concrete increased the maintenance process interval, which increases the total cost. In addition, the obtained restoration standard is not acceptable.

This raised the importance of employing innovative restoration material during rehabilitating heritage buildings. Accordingly, this study was commenced with the objective of investigating the impact of implementing nanatechnology, during rehabilitating heritage buildings, on the concrete mechanical so as physical properties. 
Consequently, all through the theoretical study, literature in the field of heritage building restoration and nanotechnology were investigated and comprehended, from which it was clear that the National Organization for Civilization Coordination categorized buildings according to their steadfastness and continuity into categories. In addition, from the assembled literature, it ws clear that many researches are involved in investigating the impact of adding nano-CaCo3 and Kaoline. For example, S.I. Zaki, et al 2018 compared the impcat of Nano calcium carbonate and Nano kaoline properties. Their results confirmed that the proportions of calcium carbonate nanoparticles of $\mathrm{CaCo} 3$ and nano kaoline that reduced concrete flowability and improved compressive strength of concrete were $1 \%$ and $7 \%$, respectively. In addition, Mohamed, A. M. 2016 studied the effect of nano materials on flexural and compressive strength of concrete of Nano-Silica (NS), Nano-Clay (NC) and NS together with NC, his results flagged-out that nano particles improved the concrete mechanical properties Furthermore, Kaszynska.2003 advocated that the application of Self-Consolidating Concrete "SCC" was efficient, her results confirmed the importance of superplasticizer, she designated that SCC was an efficient material for repairing concrete structures. 
Journal of Environmental Sciences (JES)

Institute of Environmental Studies and Research, Ain Shams University

Adly, Michel. et al.

\section{EXPERIMENTAL STUDY}

During the experimental study, materials were prepared; mixes were obtained; restored cubes were prepared and experimental investigations to their physical and mechanical properties were carried out.

\section{IMPLENTED MATERIALS}

The implemented materials were sand, coarse aggregate and ordinary Portland cement (CEM I $52.5 \mathrm{~N}$ ), while nano kaoline and nano calcium carbonate were used as partial replacement of cement. In addition, a chemical admixture was added. The description of the implemented material was as follows:

- Cement: The used cement was Ordinary Portland (OPC), (CEM1 52.5 N) obtained from Elaskary Cement Factory with standard specifications (ESS 4756-1)

- Fine Aggregate: The employed fine aggregate was local natural siliceous sand in a regular spherical structure with a maximum grain size of $1.4 \mathrm{~mm}$ obtained from Giza Quarry with a specific gravity of 2.5. Its particle size distribution lies within the the classification of the Egyptian code (ECP 203-2018).

- Coarse Aggregate: The implemented dolomite aggregate was obtained from Attaka-suze quarry with one $\mathrm{cm}$ diameter, according to the Egyptian Code: (ECP 203-2018). 
- Chemical Admixture: A-MasterGlenium (RMC 315) was implmented. It is a third generation superplasticiser based on modified polycarboxylic ether, compatible with all types of cement. It is a dark brown liquid with a density of $1.06 \pm 0.02 \mathrm{~g} / \mathrm{cm}^{3}$ obtained from O-BASF Company in Egypt. Its properties are listed in table (1). In addition, B-ADDIBOND (65) was implemented. It was a versatile adhesive used for bonding fresh to old concrete.

- Nano Powders: The implemented nano powders were nano Calcium Carbonate and nano kaoline. They were produced by thermal activation by burning the raw material in a flat plate with a maximum layer thickness 4 $\mathrm{cm}$ at $800^{\circ} \mathrm{C}$ for 2 hours in an airtight oven in the Fire laboratory of Housing and Building Research Center (HBRC). The material was gradually cooled to air temperature $\left(27^{\circ} \mathrm{C}\right)$ so as not to agglomerate. They were examined with a transmission electron microscope (i.e. JEOL -JEM - 2100), figure (1) in the National Research Centre to determine their particle size. Their sizes are listed in table (2). The implemented nanoparticles were as follows:

1. Nano kaoline: The implemeneted nano kaoline is montmorillonite clay (OH4 Si8 AL4 O20n) obtained from Heliopolis for mining with grinding of $25-100$ microns. It is in crystalline state characterized by longer length relative to its thickness. Figure (2) presents its TEM micrograph after burning in HBRC. 
2. Nano Calcium Carbonate: The implemented nanoCalcium carbonate (caco3) is obtained from Egyptian Carbonate company, with grinding 15 microns in crystalline state with a spherical shape. Figure (3) presents its TEM micrograph after burning.

Table(1): Technical Data and Physical properties of Master Glenium

\begin{tabular}{||c|c|c|c|c|c|c||}
\hline Form & Colour & $\begin{array}{c}\text { Specific } \\
\text { gravity }\end{array}$ & pH & Sulphate & $\begin{array}{c}\text { Alkali } \\
\text { content }\end{array}$ & $\begin{array}{c}\text { Chloride } \\
\text { ion }\end{array}$ \\
\hline \hline $\begin{array}{c}\text { Viscous } \\
\text { liquid }\end{array}$ & cream & $\begin{array}{c}1.075- \\
1.085 \text { at } \\
25 \mathrm{C} 0\end{array}$ & $5-8$ & $\begin{array}{c}\text { Less than } \\
1 \mathrm{gm} / 1 \mathrm{tr}\end{array}$ & $\begin{array}{c}\text { Less } \\
\text { than } 5 \\
\mathrm{gm} / 1 \mathrm{tr}\end{array}$ & $\begin{array}{c}\text { Less than } \\
0.1 \% \mathrm{w} / \mathrm{v} \\
\text { (nil) }\end{array}$ \\
\hline
\end{tabular}

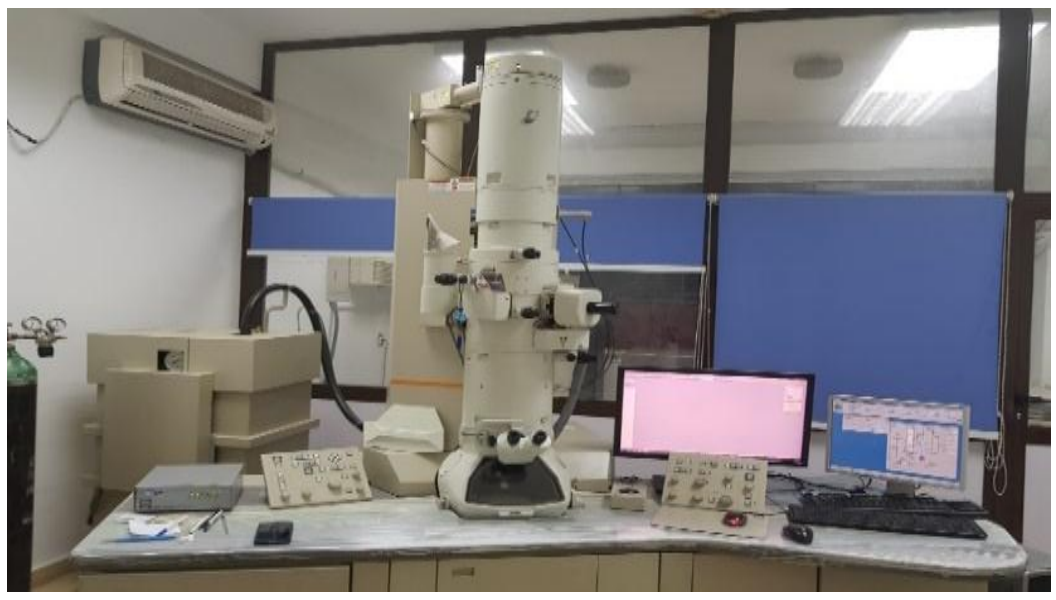

Fig(1): TEM JEOL -JEM - 2100 
Journal of Environmental Sciences (JES)

Institute of Environmental Studies and Research, Ain Shams University

Adly, Michel. et al.

Table (2): Physical properties of nano particles

\begin{tabular}{||c|c|c|}
\hline Nano Type & color & Mean Partical Size (nm) \\
\hline \hline Nano Calcium Carbonate & White & 60 \\
\hline Nano kaoline & Light Cream & 70 \\
\hline
\end{tabular}

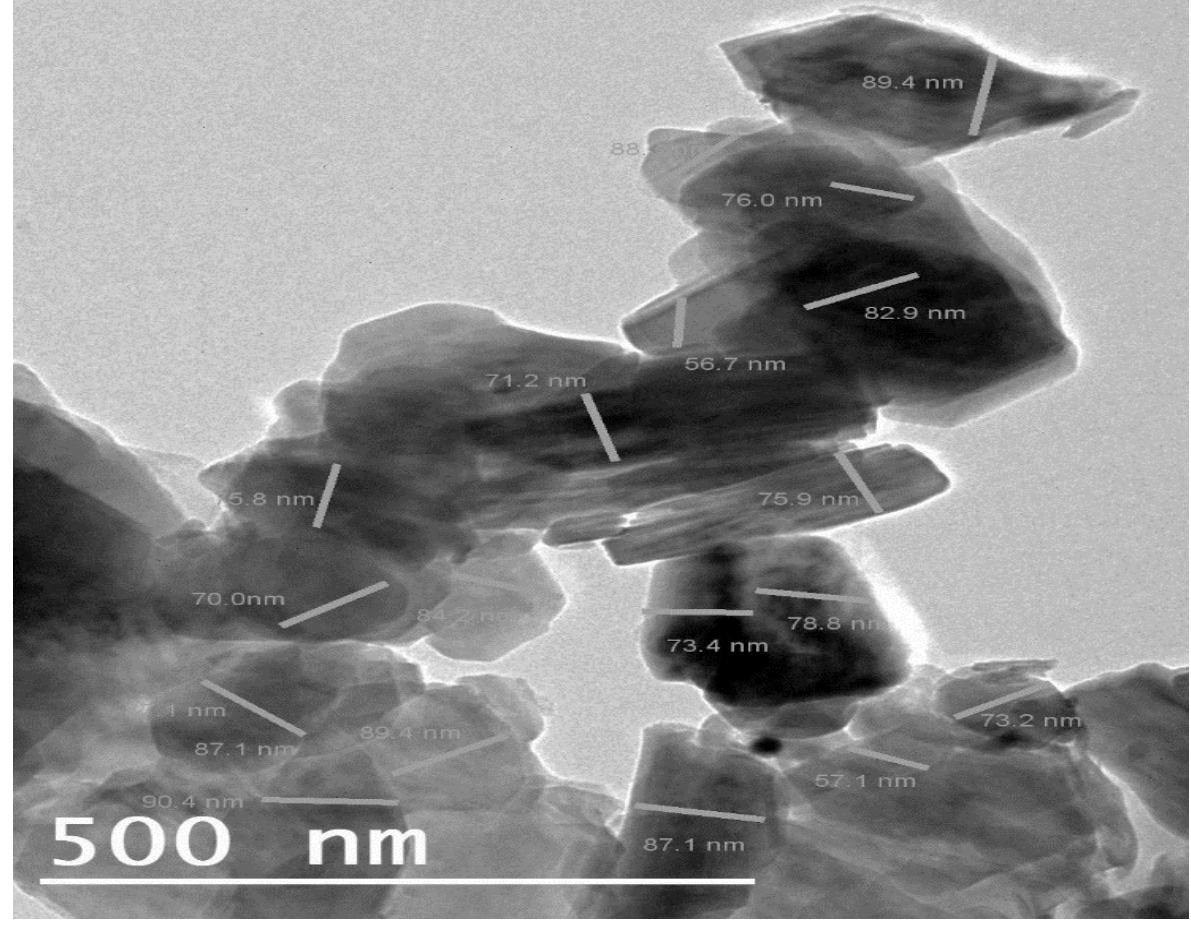

Fig(2): TEM micrograph for nano kaoline and mean particles size $70 \mathrm{~nm}$

Vol.(50); Iss.(2); No.(3); Mar..2021

ISSN $1110-0826$ 


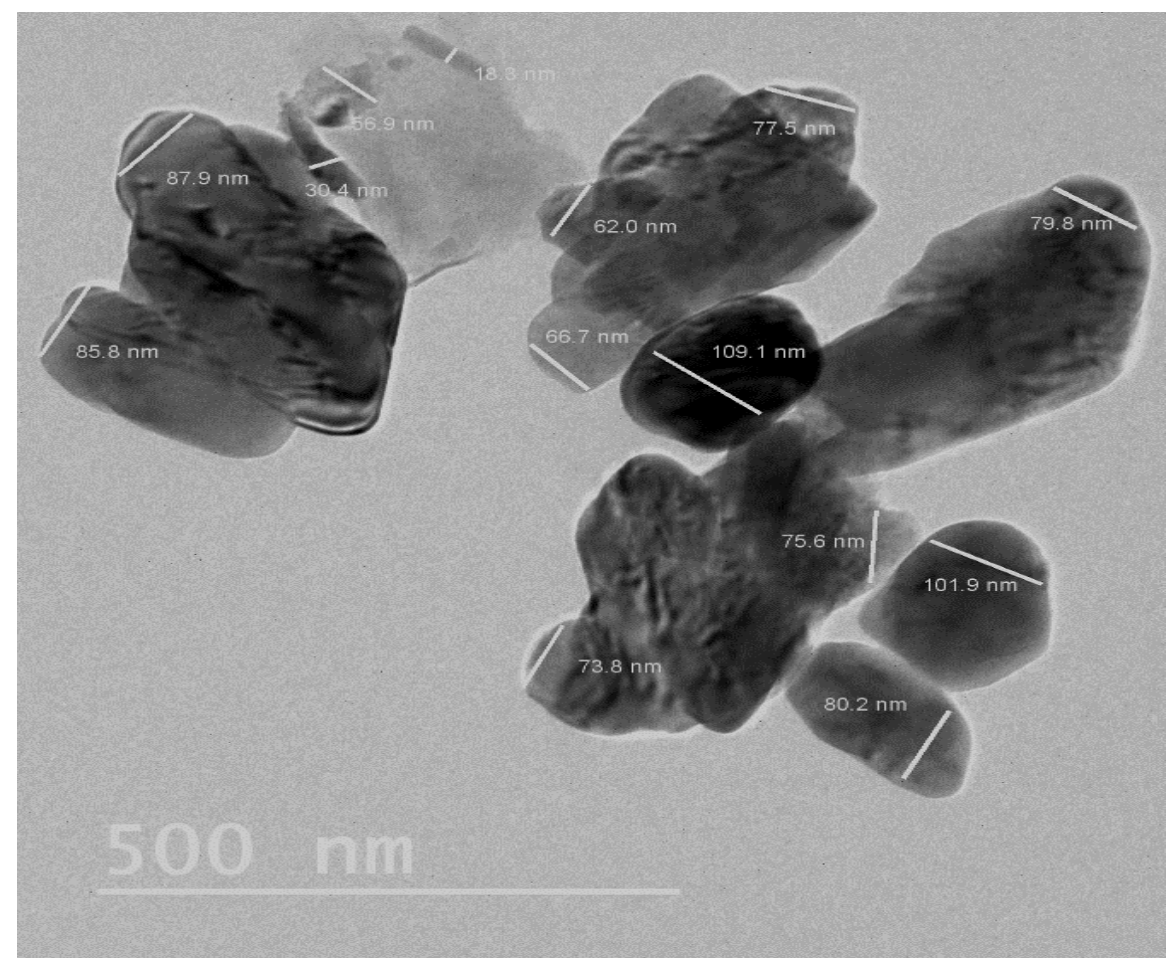

Fig (3): TEM micrograph for nano $\mathrm{CaCo} 3$ and mean particles size $60 \mathrm{~nm}$

a) MIXES PREPARATION: During the experimental study, a reference mix "C0" (without nano materials) was prepared for comparison purposes.

In addition, 9 concrete mixes were prepared, according to ECP, NO.203, 2018. Their cement content was $450 \mathrm{~kg} / \mathrm{m} 3$. Their W/C was 0.28 . The implemented cemet type was CEM I 52.5. The water temprature was $\sim 25 \mathrm{C}^{\circ}$. Nanomaterials (Nano clay, Nano Calcium Carbonate) were mixed with 3\% Master Glenium 315RMC admixture by wieght of cementitous materials. Concrete samples were prepared, mixed, casted, cured and tested in the Material Laboratory of HBRC. 


\section{The mixes were as follows:}

- Three mixes were prepared by adding Nano-CaCo3 to concrete at a percentages of 1,2 and 3\%, as a partial replacement of cement.

- Three mixes were prepared by adding NK to concrete at a percentages of 5,6 , and $7 \%$, as a partial replacement of cement.

- Two hybrid mixes were obtained by adding $1 \% \mathrm{NCa}+5 \% \mathrm{NK}$ and $0.5 \%$ $\mathrm{NCa}+4.5 \% \mathrm{NK}$, as partial replacement of cement.

b). EXPERIMENTAL PROGRAM: An experimental program was designed, it was classified into two main parts, as follows:

- The first part inspected 9 concrete mixes to study the impact of using nanomaterials with diffrent ratios (Nano Kaoline, Nano Calcium Carbonate) on the properties of fresh and hardened concrete in comparison to the reference mix "C0" (without nano materials), as listed in table (4).

- The second part tested an old $5 \mathrm{~cm}$ side concerte cube extracted from a 15 $\mathrm{cm}$ side test cube, where the additives ADDIBOND 65 was impemented to ensure adheision between old and new concrete.

\section{c). INVESTIGATING CONCRETE PROPERTIES}

\section{Fresh mix and hardened concrete were investigated, as follows:}

- For the fresh concrete tests: Slump test was carried out to measure the consistency of concrete.

- For the hardened concrete tests: the following tests were carried out: 
- Compressive Strength Test: The compressive strength is measured by testing concrete specimens in a compression-testing machine at 7,28 and 60 day.

Characterization by Scanning Electron Microscope (SEM): Scanning electron microscope micrographs were carried out in HBRC to interpret the compressive strength results for control samples cubes and of concrete containing nanomaterials.

Table (4): concrete mix proportions.

\begin{tabular}{||c|c|c|c|c|c|c|c||}
\hline \multirow{2}{*}{$\begin{array}{c}\text { MIX } \\
\text { NO }\end{array}$} & \multirow{2}{*}{\begin{tabular}{c} 
MIX of \\
\cline { 3 - 8 }
\end{tabular}} & \multirow{2}{*}{ CEMENT } & $\begin{array}{c}\text { Fine } \\
\text { aggrgate }\end{array}$ & $\begin{array}{c}\text { Coars } \\
\text { aggregate }\end{array}$ & Nano & Water & \multirow{2}{*}{ RMC315 } \\
\hline \hline C0 & Control & 450.0 & 720 & 1200 & 0 & 126 & 13.5 \\
\hline NK1 & NK5\% & 414.0 & 720 & 1200 & 22.5 & 126 & 13.5 \\
\hline NK2 & NK6\% & 409.5 & 720 & 1200 & 27.0 & 126 & 13.5 \\
\hline NK3 & NK7\% & 405.0 & 720 & 1200 & 31.5 & 126 & 13.5 \\
\hline NCa1 & NCoCa31\% & 432.0 & 720 & 1200 & 4.5 & 126 & 13.5 \\
\hline NCa2 & NCoCa32\% & 427.5 & 720 & 1200 & 9.0 & 126 & 13.5 \\
\hline NCa3 & NCoCa33\% & 423.0 & 720 & 1200 & 13.5 & 126 & 13.5 \\
\hline HN1 & Hybrid 6\% & 409.5 & 720 & 1200 & 27.0 & 126 & 13.5 \\
\hline HN2 & Hybrid 5\% & 414.0 & 720 & 1200 & 22.5 & 126 & 13.5 \\
\hline
\end{tabular}

\section{Where :}

\section{$\mathrm{C} 0=$ Control Mix}

NK1,2,3= includes 1,3,5\% Nano kaoline by weight of cement, respectively.

NCa1,2,3=includes $5,6,7 \%$ NCaCo3 by weight of cement, respectively.

$\mathrm{HN} 1=(5 \% \mathrm{~N}$ kaoline $+1 \%$ Nano calcium carbonate $)(6 \%$ Hybrid $)$.

$\mathrm{HN} 2=(4.5 \% \mathrm{~N}$ kaoline $+0.5 \%$ Nano calcium carbonate $)(5 \%$ Hybrid $)$. 
d). INVESTIGATING RESTORED CONCRETE: Experiments were carried out to evaluate the impact of restoring old concrete by nanoparticles concrete on its mechanical and physical properties, where the mixes partially replaced the structural elements needed to be restored in the Egyptian Syndicate.

Primarily, a full knowledge was perceived to the historical, architectural and Engineering aspects of the building. In addition, the state of the Egyptian Syndicate was monitored to identify the construction matrials; designate the prevailing damage factor; distinguish the damage type and to identify the restoration method, Furthermore, they were documented.

the restoration steps proceeded by extracting old concrete cubes $(15 \times 15 \times 15 \mathrm{~cm})$ from cracked regions of the building. the extracted old cubes were partially replaced by the different nanoparticles concrete mixes $(5 \times 5 \times 5$ $\mathrm{cm}$ ) that were bonded by additives (ADDIBOND), figure (4). Compression tests were carried out to the old concrete cubes restored by the nanoparticles concrete.

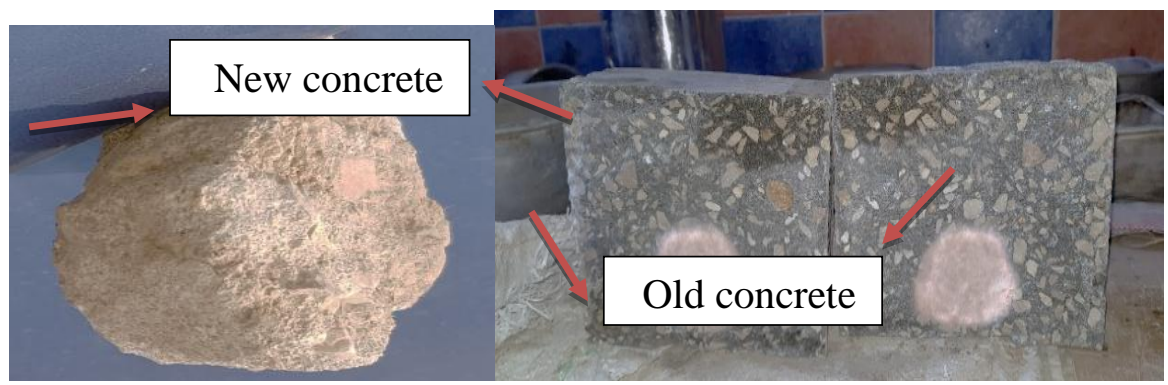

Figure (4): Old concrete bonded to nanoparticles concrete 
Journal of Environmental Sciences (JES)

Institute of Environmental Studies and Research, Ain Shams University

Adly, Michel. et al.

\section{RESULTS ANALYSIS AND DISCUSSION}

Throughout the analytical study, the obtained results were analyzed and presented on graphs and listed in figures for fresh (i.e. slump test), hardened concrete (i.e. comressive strength) and micro structure, as follows:

a) FRESH CONCRETE SLUMP TEST RESULT ANALYSIS: The slump experimental results were analyzed and scrutinized in order to signpost the impact of the different nanoparticles on fresh concrete:, from which the following was obtained:

- Table (5) lists the slump test results.

- Figure (5) presents the change in slump results for all mixes and the reference mix. The table and figure indicated that slump results were reduced by increasing the proportion of nano-kaoline and nano-CaCoz. As for the hybrid mix, the slump results increased at higher percentages, In addition, it was observed that all mixes slump results were less than the reference mix. Furthermore, the lowest slump values were obtained for mixes Nk3 and HN2, which indicated their low workability.

\section{b) HARDENED CONCRETE COMPRESSIVE STRENGTH}

RESULTS ANALYSIS: Compressive experimental results were analyzed and scrutinized in order to designate the impact of the different nanoparticles on hardened concrete, from which the following was deduced:

- Table (6) lists the compressive test results. The table indicated the effect of nanomaterials at different replacement proportions of cement on the compressive strength after 7, 28 and 60 days, for $\mathrm{NK}, \mathrm{NCaCo}_{3}$ and hybrid 
in comparison to reference mix. In addition, the table indicated that the highest compressive strength were achieved in NK1 (i.e. $674.5 \mathrm{~kg} / \mathrm{cm}^{2}$ ), HN2 (i.e. $656 \mathrm{~kg} / \mathrm{cm}^{2}$ ) and reference mix (i.e. $585.6 \mathrm{~kg} / \mathrm{cm}^{2}$ ). Moreover, it was obvious that nanoparticles increased the concrete compressive strength by 14- 22 relative to the reference mix. Likewise, the table indicated the impact of Nano-Koaline replacement ratios. Obvious was that the compressive strength was reduced at higher ratios of nano kaoline above $5 \%$, where compressive strength were $516,600,675 \mathrm{~kg} / \mathrm{cm}^{2}$, at 7 , 28 and 60 days. Similarly, the table designated the impact of Nano CaCo3 at replacement ratios of 1,2 and $3 \%$. Obvious was that $1 \% \mathrm{NCaCo}_{3}$ affected the early-age hardening process, which indicates that nano- $\mathrm{CaCo}_{3}$ addition is a hardening accelerator. Correspondingly, the table flagged out the impact of Hybrid Nano replacement ratios on compressive strength. Aparent was that lowering the percentage than $5 \%$ increases the concrete compressive strength, where the suitable percentage was $(4.5 \%$ kaoline $\left.+0.5 \% \mathrm{CaCo}_{3}\right)$, as it elevated the compressive strength by $12 \%$ above reference mix. Compressive strength increase is due to efficiency of nano particles in activating chemical reaction that consumes calcium hydroxide forming (C-S-H).

- Figure (6) presents the change in compressive results for mixes with nano kaoline and the reference mix. It presents the impact of nano kaoline on the concrete compressive strength, it was obvious that implementing 
higher ratios than 5\%, increased the compressive strength at 7, 28 and 60 days, (i.e. $516,600,675 \mathrm{~kg} / \mathrm{cm}^{2}$ ). Furthermore, the figure indicated that the compressive strength results with NK 5\% were higher by $15 \%$ above the reference mix. This is due to the nano particles presence that activates the chemical reaction that consumes calcium hydroxide to form additional (C$\mathrm{S}-\mathrm{H})$, which is a gel material.

- Figure (7) presents the change in compressive results for mixes with nano $\mathrm{CaCo}_{3}$ and the reference mix. The figure flagged out that the mix with $1 \%$ $\mathrm{NCaCo}_{3}$ recorded the highest compressive strength (i.e. 487, 545, 605 $\mathrm{kg} / \mathrm{cm}^{2}$ ) at 7,28 , and 60 days, respectively. This indicated that the compressive strength increased $6 \%$ above reference mix (i.e. adding $1 \%$ $\mathrm{NCaCO}_{3}$, achieved a compressive strength of $605 \mathrm{~kg} / \mathrm{cm}^{2}$ ) .

- Figure (8) presents the compressive results for mixes with hybrid nano and reference mix.

Table (5): Slump test results for all concrete mixes (after mixing)

\begin{tabular}{||c|c|c|c|c|c|c|c|c|c||}
\hline $\begin{array}{c}\text { MIX } \\
\text { NO }\end{array}$ & C0 & NK1 & NK2 & NK3 & NCa1 & NCa2 & NCa3 & HN1 & HN2 \\
\hline \hline $\begin{array}{c}\text { Slump } \\
\text { (mm) }\end{array}$ & 165 & 130 & 120 & 100 & 150 & 130 & 110 & 110 & 100 \\
\hline
\end{tabular}

Where : $(\mathrm{C} 0=$ Control Mix - NK1,2,3= includes 1,3,5\% Nano kaoline NCa1,2,3=includes 5,6,7\% $\mathrm{NCaCo} 3-\mathrm{HN} 1=(6 \%$ Hybrid $)-\mathrm{HN} 2(5 \%$ Hybrid)). 
Journal of Environmental Sciences (JES)

Institute of Environmental Studies and Research, Ain Shams University

Adly, Michel. et al.

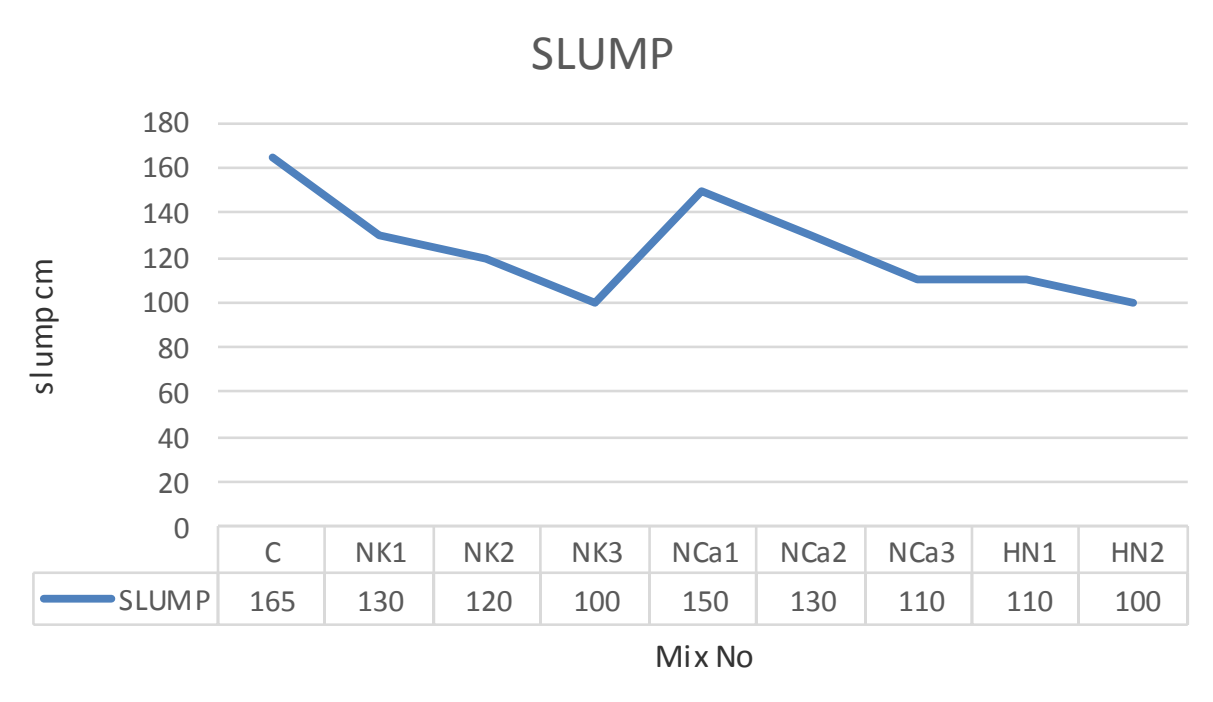

Figure(5): slump test results for all mixes

\section{Where :}

$\mathrm{C} 0=$ Control Mix

NK1,2,3= includes 1,3,5\% Nano kaoline by weight of cement, respectively.

$\mathrm{NCa} 1,2,3=$ includes $5,6,7 \% \mathrm{NCaCo} 3$ by weight of cement, respectively.

$\mathrm{HN} 1=(5 \% \mathrm{~N}$ kaoline $+1 \%$ Nano calcium carbonate) $(6 \%$ Hybrid $)$.

$\mathrm{HN} 2=(4.5 \% \mathrm{~N}$ kaoline $+0.5 \%$ Nano calcium carbonate $)(5 \%$ Hybrid $)$. 
Journal of Environmental Sciences (JES)

Institute of Environmental Studies and Research, Ain Shams University

Adly, Michel. et al.

Table (6): compressive strength test results for all mixes

\begin{tabular}{|c|c|c|c|}
\hline MIX & $\begin{array}{l}\text { Time } \\
\text { (Days) }\end{array}$ & $\begin{array}{c}\text { Compressive strength } \\
(\mathrm{kg} / \mathrm{cm} 2)\end{array}$ & Details \\
\hline \multirow{3}{*}{$\mathrm{C}$} & 7 & 431 & \multirow{3}{*}{ control } \\
\hline & 28 & 513 & \\
\hline & 60 & 585.6 & \\
\hline \multirow{3}{*}{ NK1 } & 7 & 516 & \multirow{3}{*}{$\begin{array}{c}5 \% \\
\text { Nano kaoline }\end{array}$} \\
\hline & 28 & 600 & \\
\hline & 60 & 674.5 & \\
\hline \multirow{3}{*}{ NK2 } & 7 & 479.5 & \multirow{3}{*}{$\begin{array}{c}6 \% \\
\text { Nano kaoline }\end{array}$} \\
\hline & 28 & 603 & \\
\hline & 60 & 610 & \\
\hline \multirow{3}{*}{ NK3 } & 7 & 419 & \multirow{3}{*}{$\begin{array}{c}7 \% \\
\text { Nano kaoline }\end{array}$} \\
\hline & 28 & 534.5 & \\
\hline & 60 & 534 & \\
\hline \multirow{3}{*}{ NCa1 } & 7 & 487 & \multirow{3}{*}{$\begin{array}{c}1 \% \\
\text { Nano } \mathrm{CaCo} 3\end{array}$} \\
\hline & 28 & 545 & \\
\hline & 60 & 605 & \\
\hline \multirow{3}{*}{$\mathrm{NCa} 2$} & 7 & 508 & \multirow{3}{*}{$\begin{array}{c}2 \% \\
\text { Nano } \mathrm{CaCo} 3\end{array}$} \\
\hline & 28 & 523 & \\
\hline & 60 & 546 & \\
\hline \multirow{3}{*}{$\mathrm{NCa} 3$} & 7 & 488 & \multirow{3}{*}{$\begin{array}{c}3 \% \\
\text { Nano CaCo3 }\end{array}$} \\
\hline & 28 & 526 & \\
\hline & 60 & 561 & \\
\hline \multirow{3}{*}{ HN1 } & 7 & 431.5 & \multirow{3}{*}{$5 \% \mathrm{NK}+1 \% \mathrm{NCaCo} 3$} \\
\hline & 28 & 513 & \\
\hline & 60 & 549 & \\
\hline \multirow{3}{*}{ HN2 } & 7 & 604 & \multirow{3}{*}{$\begin{array}{c}4.5 \% \mathrm{NK}+ \\
0.5 \% \mathrm{NCaCo} 3\end{array}$} \\
\hline & 28 & 634 & \\
\hline & 60 & 656 & \\
\hline
\end{tabular}


Journal of Environmental Sciences (JES)

Institute of Environmental Studies and Research, Ain Shams University

Adly, Michel. et al.

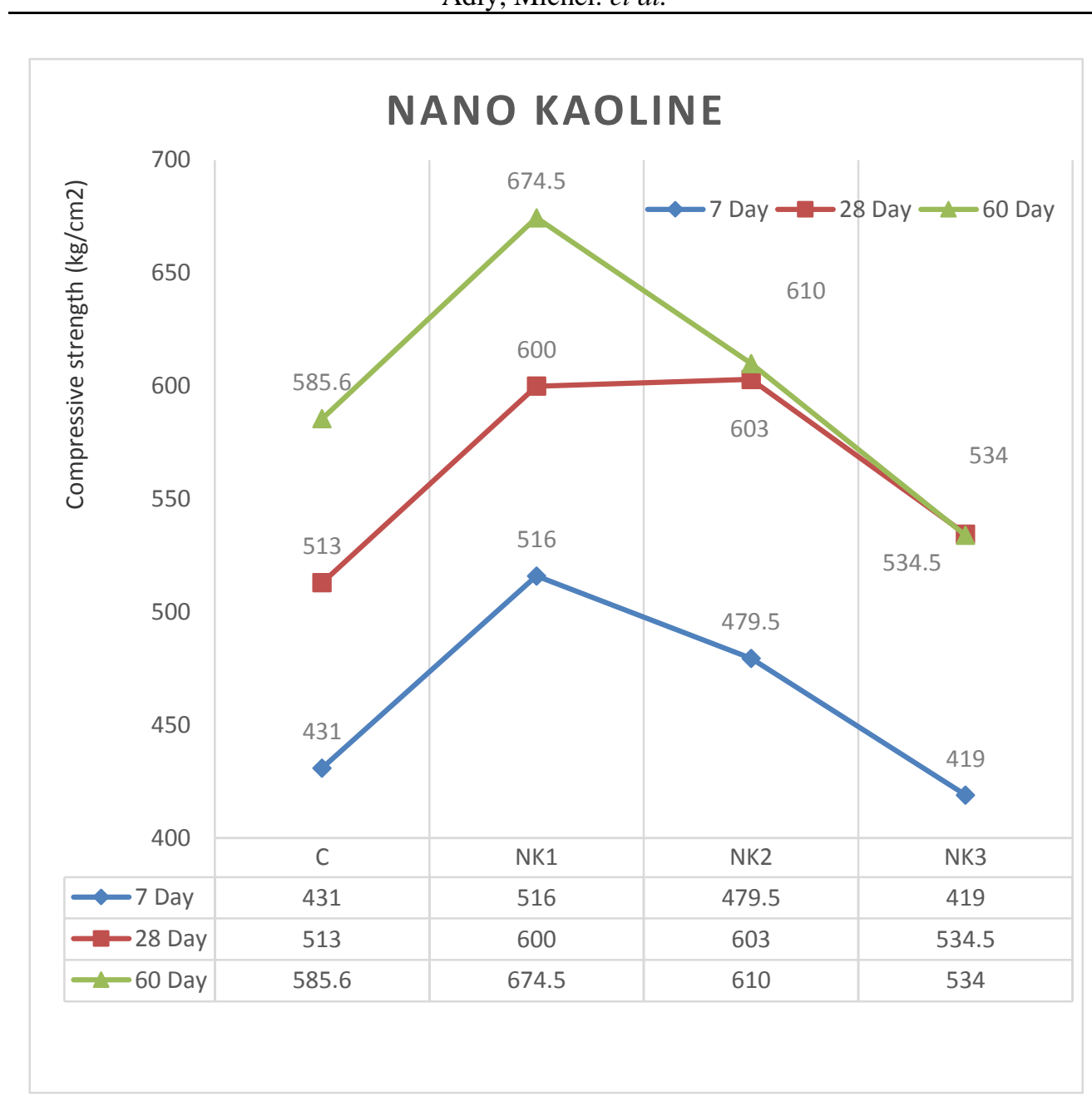

Where : $(\mathrm{C} 0=$ Control Mix $-\mathrm{NK} 1,2,3=$ includes 1,3,5\% Nano kaoline $)$.

Figure (6): Compressive strength for nano kaoline mixes compared to control mix.

Vol.(50); Iss.(2); No.(3); Mar..2021

ISSN 1110-0826 
Journal of Environmental Sciences (JES)

Institute of Environmental Studies and Research, Ain Shams University

Adly, Michel. et al.

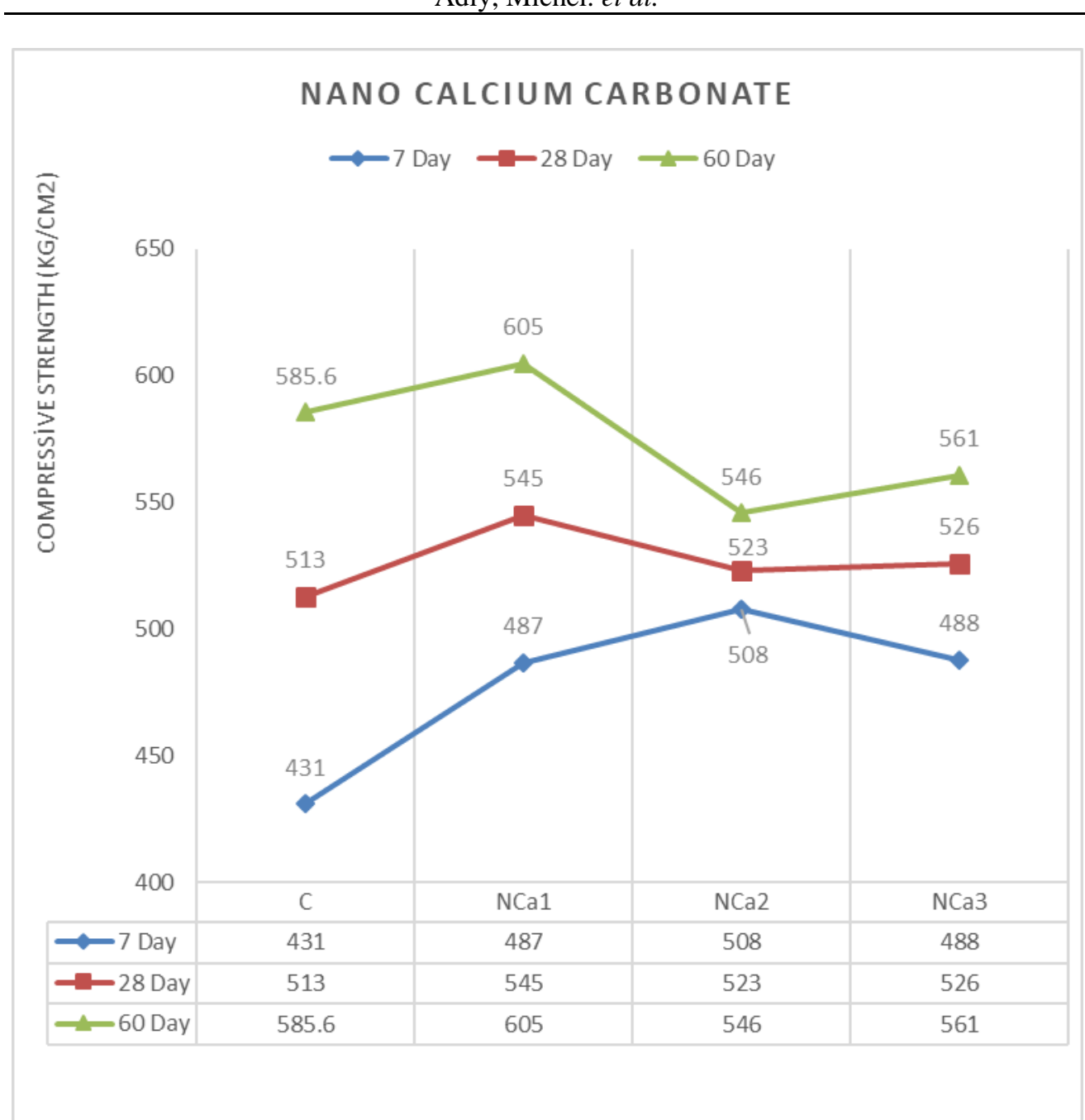

Where : $\left(\mathrm{C}_{0}=\right.$ Control Mix -NCa1,2,3=includes 5,6,7\% $\left.\mathrm{NCaCo}_{3}\right)$.

Figure(7): compressive strength for nano calcium carbonate $\left(\mathrm{NCaCo}_{3}\right)$ mixes compared to control mix. 
Journal of Environmental Sciences (JES)

Institute of Environmental Studies and Research, Ain Shams University

Adly, Michel. et al.

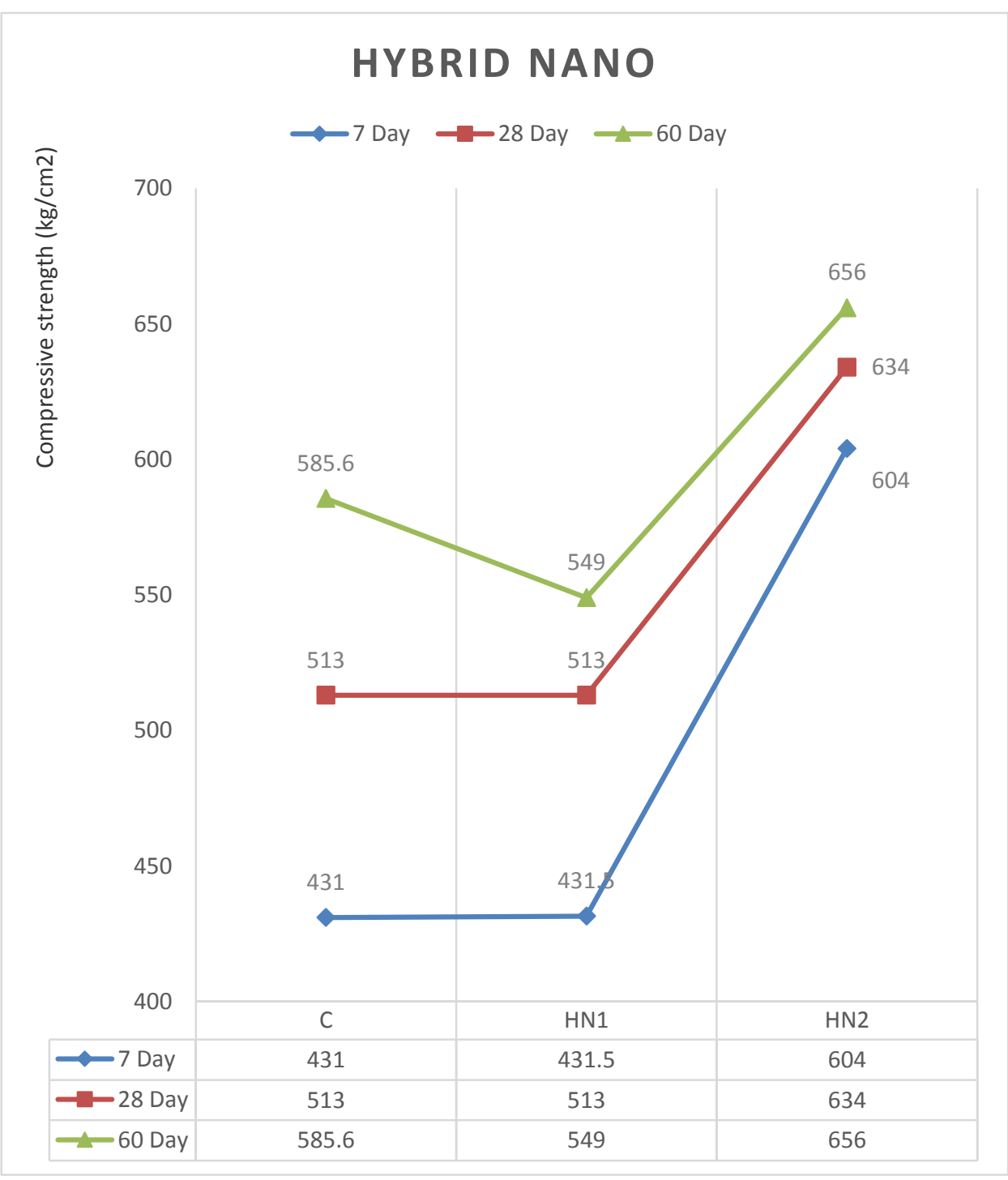

Where : $(\mathrm{C} 0=$ Control Mix $-\mathrm{HN} 1=(6 \%$ Hybrid $)-\mathrm{HN} 2(5 \%$ Hybrid $))$.

Figure(8): compressive strength for hybrid nano mixes compared to control mix.

Vol.(50); Iss.(2); No.(3); Mar..2021

ISSN 1110-0826 
Journal of Environmental Sciences (JES)

Institute of Environmental Studies and Research, Ain Shams University

Adly, Michel. et al.

\section{C.) CONCRETE RESTORATION RESULTS ANALYSIS: Experimental} results for examining the impact of employing nanoparticles in old concrete restoration were analyzed and scrutinized in order to designate the impact of the different nanoparticles on old concrete, where the following was produced:

- Table (7) lists the compression strength results, from which apparent was the following:

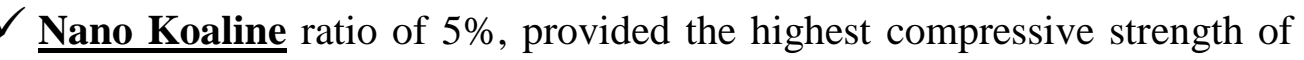
concrete. It increased the compressive strength of concrete by $11 \%$ compared to the reference mix.

$\checkmark \underline{\text { Nano CaCo3 }}$ ratio of $1 \%$ enhanced the compressive strength compared to the reference mix.

$\checkmark$ Hybrid Nano ratio of $\left(4.5 \%\right.$ Nkaoline $\left.+0.5 \% \mathrm{NCaCo}_{3}\right)$ achieved the highest compressive strength compared to the reference mix. It increased the compressive strength by $22 \%$ compared the reference mix.

- Figure (9) presents the average compressive strength of restored concrete, from which obvious was the following:

HN2 achieved the highest adhesion followed by NK1 and NCa1.

$\checkmark$ Hybrid concrete with $4.5 \%$ Nkaoline and $0.5 \%$ NCoCa3 achieved the highest compressive strength in the early-age. 
Journal of Environmental Sciences (JES)

Institute of Environmental Studies and Research, Ain Shams University

Adly, Michel. et al.

Table(7): Compressive strength of restored concrete

\begin{tabular}{|c|c|c|c|}
\hline MIX & $\begin{array}{c}\text { Time } \\
\text { (Days) }\end{array}$ & $\begin{array}{c}\text { Compressive strength } \\
(\mathrm{kg} / \mathrm{cm} 2)\end{array}$ & Details \\
\hline \multirow{3}{*}{$\mathrm{C}$} & 7 & 395.0 & \multirow{3}{*}{ control } \\
\hline & 28 & 521.3 & \\
\hline & 60 & 563.2 & \\
\hline \multirow{3}{*}{ NK1 } & 7 & 534.0 & \multirow{3}{*}{$5 \%$ (Nano kaoline) } \\
\hline & 28 & 647.5 & \\
\hline & 60 & 661.8 & \\
\hline \multirow{3}{*}{$\mathrm{NK} 2$} & 7 & 444.5 & \multirow{3}{*}{$6 \%$ (Nano kaoline) } \\
\hline & 28 & 599 & \\
\hline & 60 & 614.5 & \\
\hline \multirow{3}{*}{ NK3 } & 7 & 397.5 & \multirow{3}{*}{$7 \%$ (Nano kaoline) } \\
\hline & 28 & 546 & \\
\hline & 60 & 541 & \\
\hline \multirow{3}{*}{ Nca1 } & 7 & 580.0 & \multirow{3}{*}{$1 \%($ Nano $\mathrm{CaCo} 3)$} \\
\hline & 28 & 569.3 & \\
\hline & 60 & 593.6 & \\
\hline \multirow{3}{*}{ Nca2 } & 7 & 443 & \multirow{3}{*}{$2 \%($ Nano $\mathrm{CaCo} 3)$} \\
\hline & 28 & 507 & \\
\hline & 60 & 532 & \\
\hline \multirow{3}{*}{ Nca3 } & 7 & 436 & \multirow{3}{*}{$3 \%($ Nano $\mathrm{CaCo} 3)$} \\
\hline & 28 & 507 & \\
\hline & 60 & 584 & \\
\hline \multirow{3}{*}{ HN1 } & 7 & 440.5 & \multirow{3}{*}{$5 \%$ Nkaoline $+1 \% \mathrm{NCaCo} 3$} \\
\hline & 28 & 541 & \\
\hline & 60 & 565 & \\
\hline \multirow{3}{*}{ HN2 } & 7 & 561 & \multirow{3}{*}{$4.5 \%$ Nkaoline $+0.5 \% \mathrm{NCaCo} 3$} \\
\hline & 28 & 610 & \\
\hline & 60 & 686 & \\
\hline
\end{tabular}


Journal of Environmental Sciences (JES)

Institute of Environmental Studies and Research, Ain Shams University

Adly, Michel. et al.

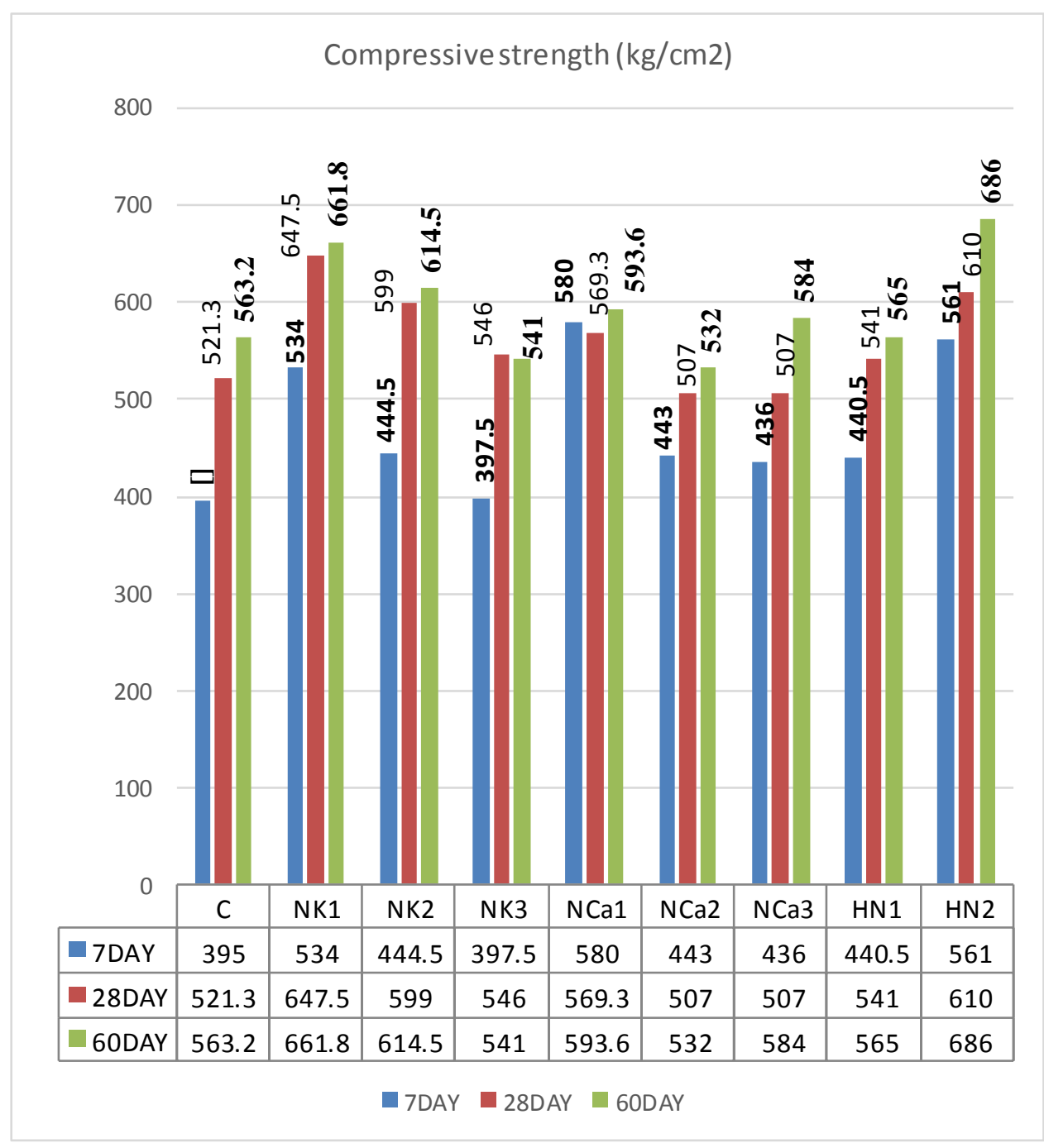

Where: $\left(\mathrm{C}_{0}=\right.$ Control Mix - NK1,2,3= includes $1,3,5 \%$ Nano kaoline $\mathrm{NCa} 1,2,3=$ includes $5,6,7 \% \mathrm{NCaCo}_{3}-\mathrm{HN} 1=(6 \%$ Hybrid $)-\mathrm{HN} 2$ (5\% Hybrid) $)$.

Figure(9): compressive strength for simulation of restoration concrete. 
f.) MICRO STRCTURE RESULTS ANALYSIS: Hardened concrete that provided the suitable results (i.e. NK1 and Nca1) micro strcture study results were analyzed and scrutinized (It is to be noted that SEM samples were cut from crushed cubes with regular shape and flat surface), from which the following was produced:

- Figure (10) presents the SEM photograph of the reference mix without nano particles, where it was found that the inter filler zone was calciumsilicate-hydrate (C-S-H) gel that existed in the form of 'stand-alone' clusters. The photograph indicated the presence of voids and weakness bonds between the aggregate and the cement paste.

- Figure (11) presents the SEM photograph of concrete mix with 5\% $\underline{\text { Nano }}$ $\underline{\text { Kaoline }}$, where it was different from the reference mix. The photograph indicated the presence of crystals and the texture of hydrate products was denser and compact. This will enhance the mechanical properties and strengthen the structure. lot of crystal bonding in the structure. In addition, the photograph indicated the compact structure due to nano Kaoline nucleation effect and super filling effect that make the concrete dense with excellent mechanical properties.

- Figure (12) presents a SEM photograph for concrete mix with $1 \%$ nano $\mathrm{CaCO}_{3}$, where no voids were present with good strength bonds between aggregate and cement paste. The photograph indicated dense and compact structure of concrete mix with enhanced mechanical properties due to 
Journal of Environmental Sciences (JES)

Institute of Environmental Studies and Research, Ain Shams University

Adly, Michel. et al.

adding nano $\mathrm{CaCO}_{3}$, as it activates of the hydration of cement and reacts with $\mathrm{CH}$ to form C-S-H gels.

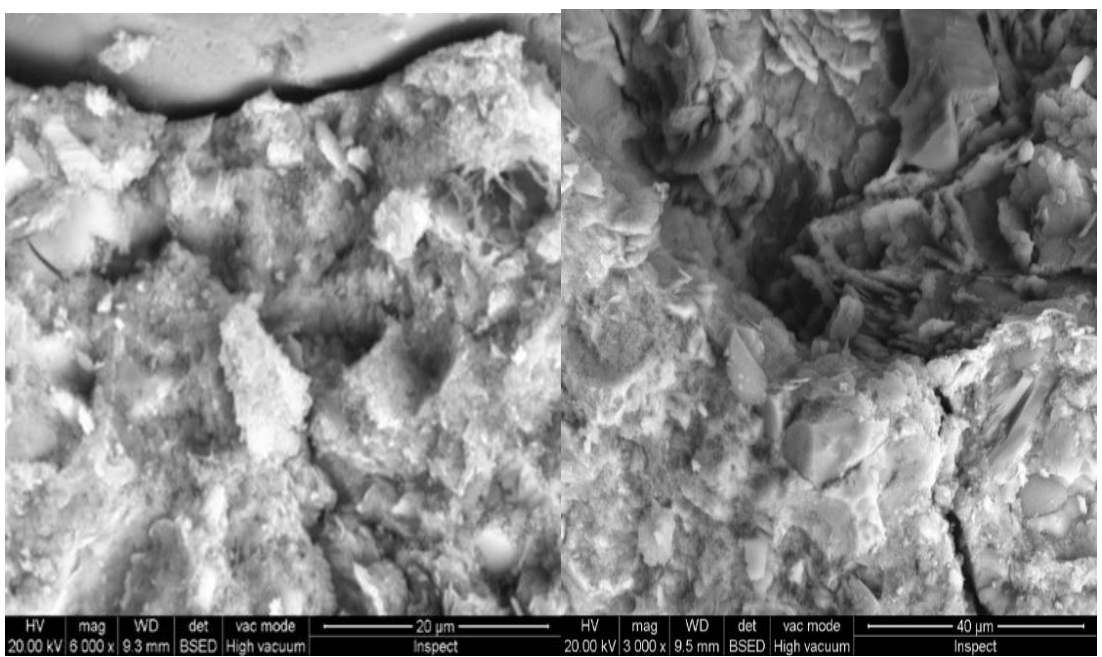

Figure(10): SEM micrographs of concrete without nanoparticals. C) N-0\% $(6000,3000 \mathrm{mag})$

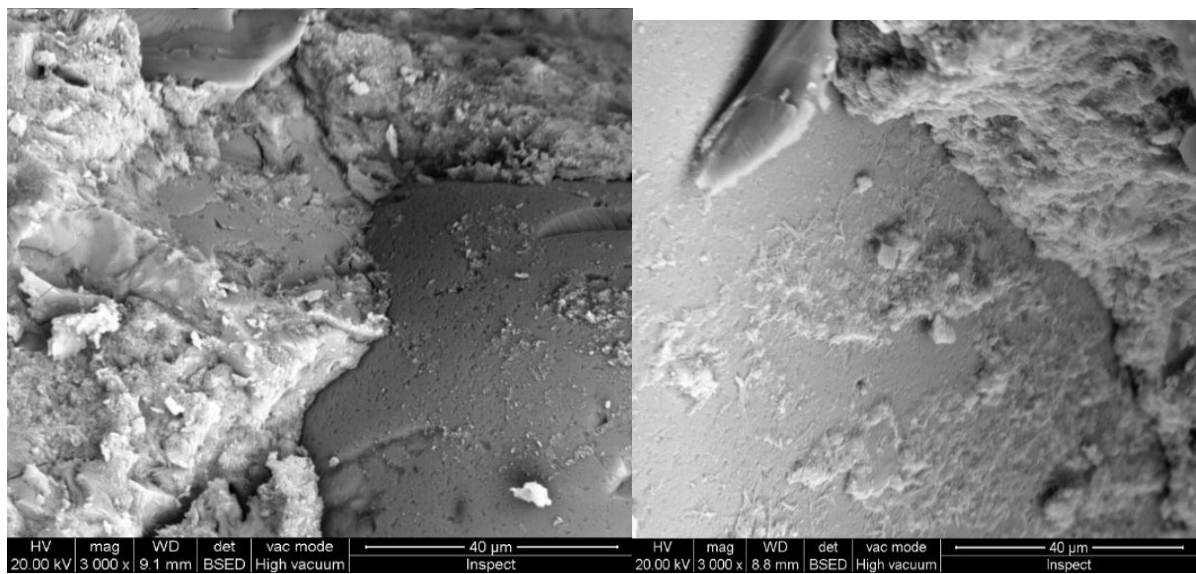

Figure (11): SEM micrographs of concrete with 5\% nano kaoline NK) N-5\% $(6000,3000 \mathrm{mag})$ 


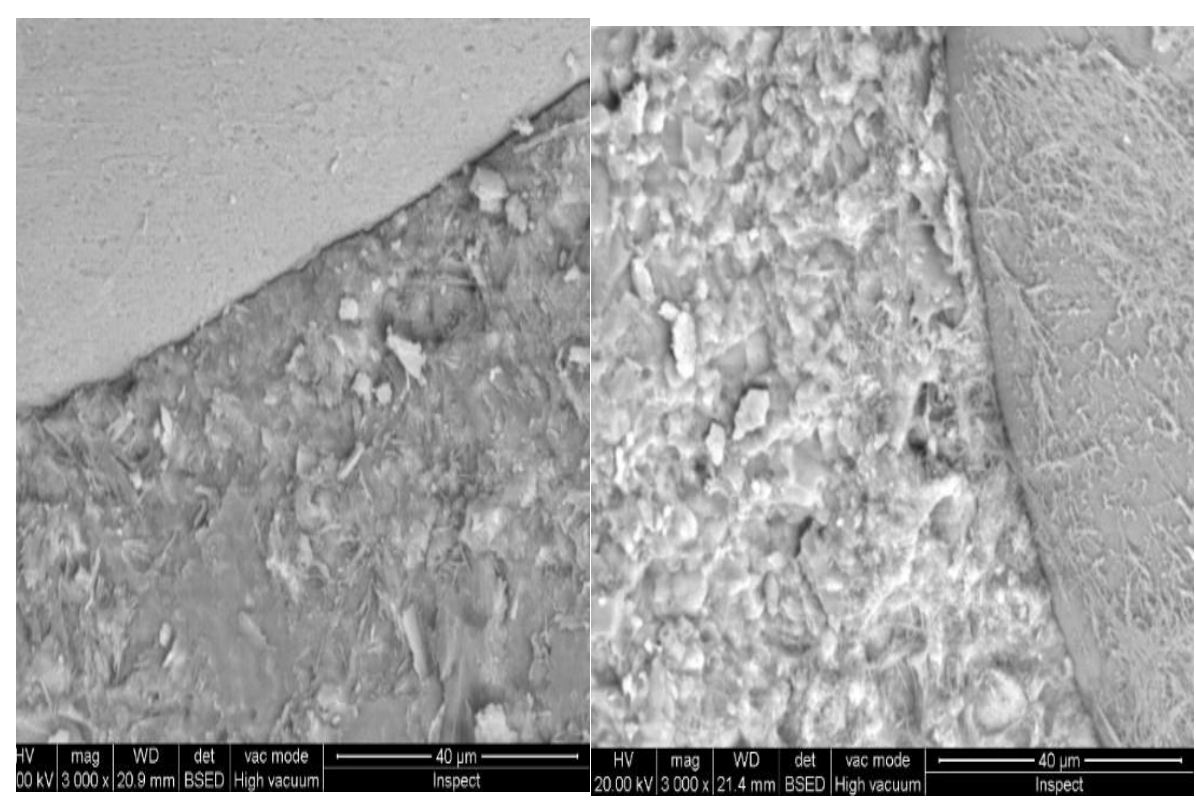

Figure (12): SEM micrographs of concrete with $1 \%$ nano calcium carbonate $\mathrm{NCa}) \mathrm{N}-1 \%(6000,3000 \mathrm{mag})$

\section{CONCLUSIONS}

The following are the deduced conclusions from the present study:

- The results indicated that adding nanoparticles reduced the concrete workability and its compressive strength, in comparison to the reference mix.

- The results designated that the suitable amount of the nano- $\mathrm{CaCo}_{3}$ and NK nanoparticles were $1 \%$ and $5 \%$, respectively. 
- The hybrid nanoparticle proper amount was $0.5 \%$ for nano- $\mathrm{CaCo}_{3}$ and $4.5 \%$ for $\mathrm{NK}$, this proportion increased the hardening; achieved a better compressive strength so as adhesion to heritage building concrete and enhanced water permeability, in comparison to the reference mix.

- Restoration with nanomaterials enhanced the bond between old to nanoparticles concrete; compressive strength; impermeability and restoration quality.

- The SEM micrographs indicated that NK provided a dense concrete.

- The SEM indicated that adding $\mathrm{NCaCo}_{3}$ up to $1 \%$ increases compressive strength.

\section{REFERENCES}

وزارة الثقافة- الجهاز القومي للتنسيق الحضاري. الاصدار الاول - الطبعة الاولى(· • • آم). الدليل

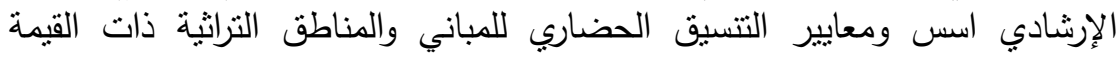

$$
\text { المتميزة. }
$$

Bhatia, S.(2016): "Nanoparticles types, classification, characterization, fabrication methods and drug delivery applications", Natural polymer drug delivery systems, (pp. 33-93). Springer, Cham.

CMB international, "Bonding Agents \& Adhesive Products", Specification, CMB, Cairo, Egypt.

Egyptian Code for Design and Execution for Concrete Structures, (2018).ECP, No, 203; 2018. 
Kaszynska, M. (2003): "Application of Self-consolidating Concrete for the Repair of Concrete Structures", In The Second International Workshop on Structural Composites for Infrastructure Applications, Cairo, Egypt.

Master Builder Solutions from BASF, (2019).(Glenium C 315): High-range, water-reducing (sp), O-BASF, Cairo, Egypt.

Mohamed, A. M. (2016): "Influence of nano materials on flexural behavior and compressive strength of concrete", HBRC journal, 12(2), 212225 .

Saaid, I. Z., Osama, A. H., \& Omar, F. E. (2018): “Comparison Between the Effect of Addtion of Nano-Calcium Carbonate and Nano-Kaoline on Developing the Properties of Reinforced Concrete" , Intellekt. Sist. Proizv., 16(3), 147-159.

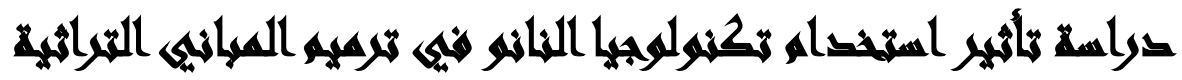

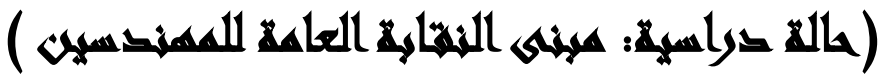

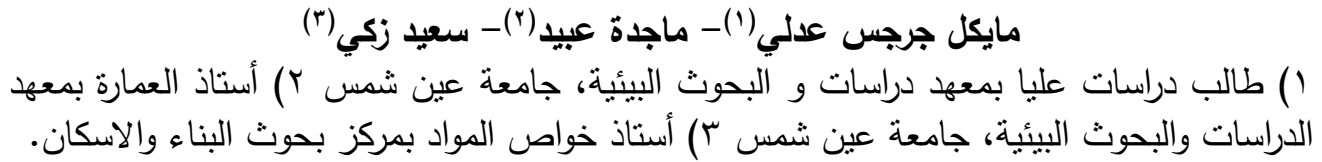

\section{المستخلصف}

نظرا لأهمية ترميم المباني التراثية في مصر ، فتهدف الدراسة الى التحقق من تأثنير استخدام

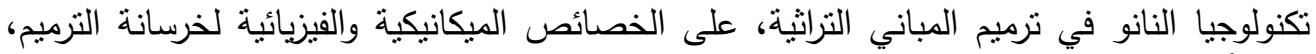
حيث أعتبر مبنى نقابة المهندسين، في شارع رمسيس، كحالة دراسية. وتشمل منهجية الدراسة تحققات نظرية ومعملية وتحليلية واستدلالية. وأثناء التحقق النظري، تم تجميع وبحث المؤلفات في مجال 
ترميم المباني التراثية وعلم النانو ـ وأثناء التحقق المعلي، تم إنتاج جسيمات نانوية من (نانو

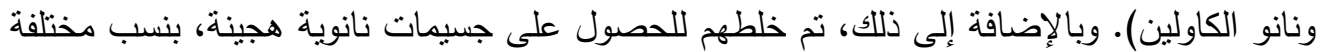

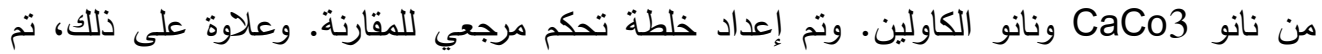

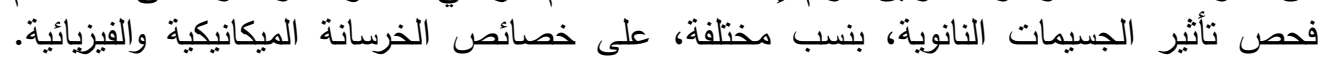

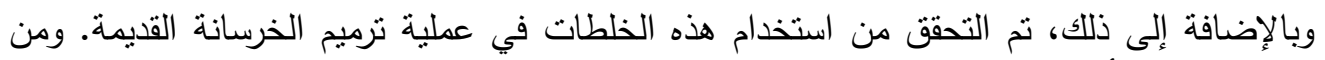

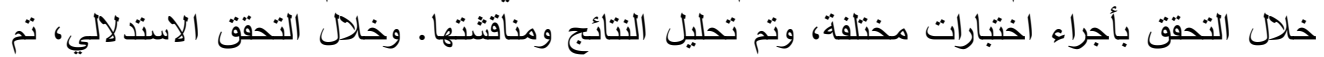

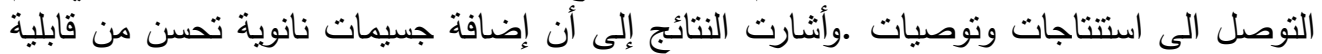

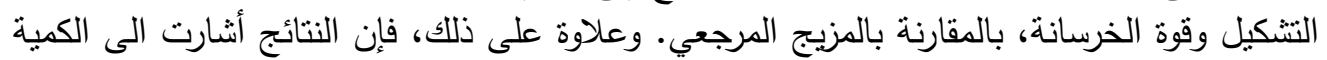

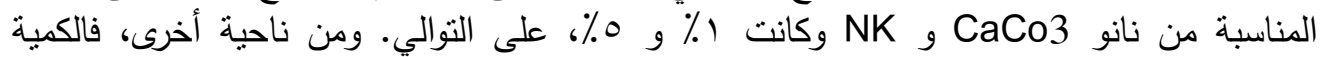

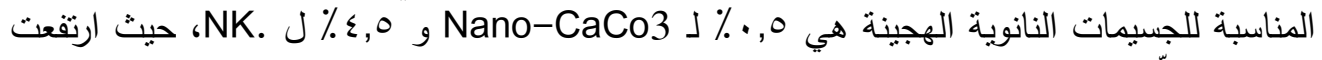

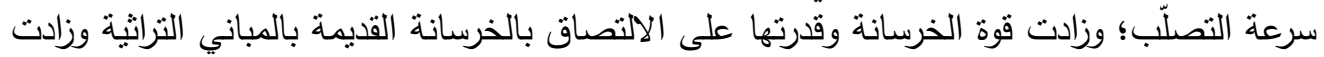

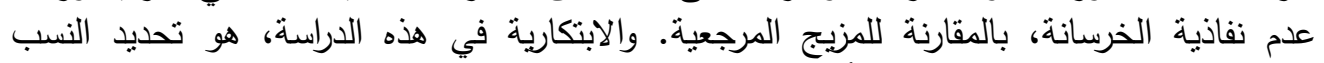
المناسبة للجسيمات النانوية لضمان أداء الخرسانة في ترميم المباني الترانية التراثية. الكلمات الرئيسية: المباني التراثية - الترميم -مواد النانو - النانية النيان الهجين. 